\title{
Highly Active Protein Surfaces Enabled by Plant-Based Polyphenol Coatings
}

\author{
Ana M. L. Sousa, ${ }^{\dagger}$ Tai-De Li, ${ }^{\ddagger}$ Sabu Varghese, ${ }^{\S}$ Peter J. Halling, ${ }^{\dagger}$ and King Hang Aaron Lau ${ }^{*}{ }^{\dagger}$ \\ ${ }^{\dagger}$ WestCHEM/Department of Pure \& Applied Chemistry, University of Strathclyde, 295 Cathedral Street, Glasgow G1 1XL, U.K. \\ ${ }^{*}$ Advanced Science Research Center (ASRC) of Graduate Center and Department of Physics in City College of New York, CUNY, \\ New York, New York 10031, United States \\ ${ }^{\S}$ Department of Chemistry, Lancaster University, Lancaster LA1 4YB, U.K.
}

\section{Supporting Information}

ABSTRACT: Proteins represent complex biomolecules capable of wide-ranging but also highly specific functionalities. Their immobilization on material supports can enable broad applications from sensing and industrial biocatalysis to biomedical interfaces and materials. We demonstrate the advantages of using aqueous-processed cross-linked polyphenol coatings for immobilizing proteins, including IgG, avidin, and various single and multidomain enzymes on diverse materials, to enable active biofunctional structures (e.g., ca. 2.2, 1.7, 1.1, and $4.8 \mathrm{mg} \cdot \mathrm{m}^{-2}$ active phosphatase on nanoporous cellulose and alumina, steel mesh, and polyester fabric, respectively). Enzyme assays, X-ray photoelectron spectroscopy, silver staining, supplemented with contact angle, solid-state ${ }^{13} \mathrm{C}$ NMR, HPLC, and ESI-MS measurements were used to characterize the polyphenols, coatings, and protein layers. We show that the functionalization process may be advantageously optimized directly for protein activity rather than the traditional focus on the thickness of the coating layer. Higher activities

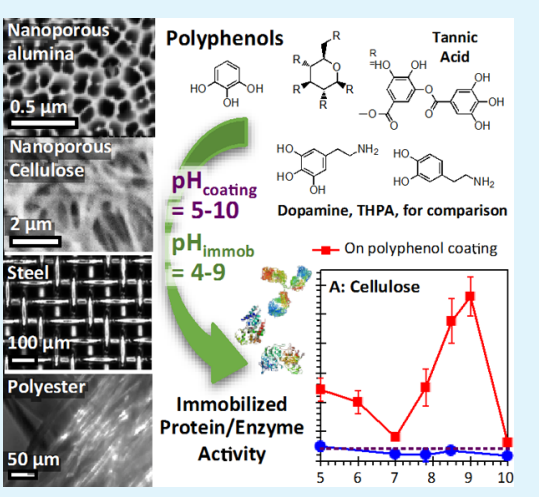
(by more than an order of magnitude in some cases) and wider process $\mathrm{pH}$ and material compatibility are demonstrated with polyphenol coatings than other approaches such as polydopamine. Coatings formed from different plant polyphenol extracts, even at lowered purity (and cost), were also found to be highly functional. Chemically, our results indicate that polyphenol coatings differ from polydopamine mainly because of the elimination of amine groups, and that polyphenol layers with intermediate levels of reactivity may better lead to high immobilized protein activity. Overall, an improved understanding of simple-to-use polyphenol coatings has been obtained, which enabled a significant development in active protein surfaces that may be applied across diverse materials and nanostructured supports.

KEYWORDS: protein immobilization, enzyme biocatalysis, polyphenol, polydopamine, biointerface

\section{INTRODUCTION}

Proteins are active biomolecules that perform many of the functions of life at mild $\mathrm{pH}$ and temperatures and can be exploited for practical applications. ${ }^{1-3}$ Enzymatic proteins in particular catalyze chemical reactions with high specificity and high rates and may be useful for environmentally and economically attractive industrial biocatalysis, ${ }^{4}$ tuneable biomaterials, ${ }^{5-7}$ and molecular sensing. ${ }^{8}$ Proteins that bind to other molecules with high specificity and/or affinity, such as immunoglobulin G and avidin, may also be used for biosensing, nanomedicine, and molecular assembly. ${ }^{9,10} \mathrm{Im}$ mobilization of such biorecognition proteins on material "supports" could further link the proteins to larger material systems to, for example, enable attachment of nanoparticles to appropriate biological targets or generate the optical, electrochemical, or structural changes necessary for biosensing. ${ }^{3,11}$ Convenient immobilization of enzymes that enables high activities would enable their economical application in industrial biocatalysis, by allowing facile separation of the proteins from the reactants to reduce the need for product purification ${ }^{12,13}$ and facilitate enzyme recovery and reuse. ${ }^{4,14,15}$

The many existing methods for immobilizing proteins on materials highlight the importance of immobilization but also the limitations of current approaches. Physical adsorption of proteins onto surfaces by nonspecific intermolecular forces (i.e., physisorption) is often the simplest method but the binding can be too weak to prevent desorption from the support surface and loss of proteins. ${ }^{4,16}$ Chemical approaches, including molecular linkers ${ }^{8,14,17,18}$ and plasma surface derivatization, ${ }^{3,19-22}$ provide stronger protein coupling via covalent, coordination, and biorecognition interactions. Facile functionalization of an expansive range of materials with wideranging protein species, including enzymes, could enable rapid development of broad applications. However, different materials and structures often require specific functionalization

Received: August 13, 2018

Accepted: October 9, 2018

Published: October 9, 2018 
methods which can take significant time and effort to be adapted or developed. ${ }^{14,23,24}$ The development of low-cost immobilization supports applicable to diverse enzyme species is a challenge especially for widening the application of industrial biocatalysis. ${ }^{4,12-16}$ Nanoporous supports are particularly relevant in this context to increase the total available surface area for immobilizing proteins and hence increase the overall activity. ${ }^{4,16}$ In all cases, increasing the activity of the immobilized protein system is a continuing challenge. $4,13,14,16$

We previously reported a "universal" cross-linked polyphenol-coating approach for the surface modification of a great variety of materials without surface preparation and demonstrated polymer grafting, nanoparticle formation, and antibacterial applications. ${ }^{25}$ Polyphenols such as tannic acid (TA) and catechins are highly abundant plant-based compounds characterized by dihydroxyphenyl (catechol) and/or trihydroxybenzoyl (galloyl) groups. Their coatings form by multiple cross-linkings between the precursor monomers and covalent and noncovalent interactions with a material surface. Unlike the popular polydopamine ( $\mathrm{pDA}$ ), which forms at $\mathrm{pH} 8.5{ }^{26-28}$ polyphenol coatings can be formed over a wider range of $\mathrm{pH}$ from mildly acidic to mildly basic and are significantly more transparent over visible wavelengths. ${ }^{25,29}$ Some researchers have pursued coordination of TA with $\mathrm{Fe}$ (III) to create biofunctional layers. $^{2,30,31}$ However, cross-linked polyphenol coatings should be more stable and may be formed using a large variety of polyphenols for potentially diverse functionality. ${ }^{29}$

Although polyphenols are often associated with enzyme inhibition, this relates mainly to certain digestive enzymes (e.g., chymotrypsin), ${ }^{32-34}$ and a polyphenol coating fixed on a surface cannot inhibit an enzyme immobilized on it if the active site is facing away from the coating. We therefore recently showed immobilization of thermolysin using poly(tannic acid) (pTA) and poly(pyrogallol) (pPG) coatings for initiating enzyme-catalyzed nanofiber self-assembly on transmission electron microscopy carbon grid and glass surfaces. ${ }^{35}$ Furthermore, although cross-linked polyphenol coatings have been tested for specific biointerfacial applications (e.g., enhancing stem cell culture, ${ }^{36,37}$ nanoparticle functionalization, ${ }^{38,39}$ protein composites, ${ }^{40,41}$ and antitumor or antibacterial surfaces ${ }^{42,43}$ ), and polyphenol/galloyl enriched polymers have been shown to capture proteins, ${ }^{44}$ the general potential and advantages of cross-linked polyphenol coatings for biomolecular functionalization have not been studied.

In this report, we demonstrate the remarkable ability of cross-linked polyphenol coatings to functionalize surfaces with proteins at high activities, across a diverse set of material supports and processing conditions, and hence demonstrate their versatility over comparable simple-to-use methods-pDA and physisorption. Proteins were chosen as a class of biomolecules for demonstration because they have activities easily reduced by surface-induced denaturation and other effects. ${ }^{13,14,16}$ We have significantly expanded upon our earlier study to a broad range of proteins (acid phosphatase, chymotrypsin, laccase, lactate dehydrogenase, horseradish peroxidase (HRP), avidin, and immunoglobulin G) and material supports (nanoporous cellulose and alumina, polyester fabric, and stainless steel mesh; see Figure 1). We found that active protein surfaces could be obtained by straightforward application of a standard functionalization protocol. However, by a combination of X-ray photoelectron spectroscopy (XPS), silver staining, contact angle, and solid-state NMR

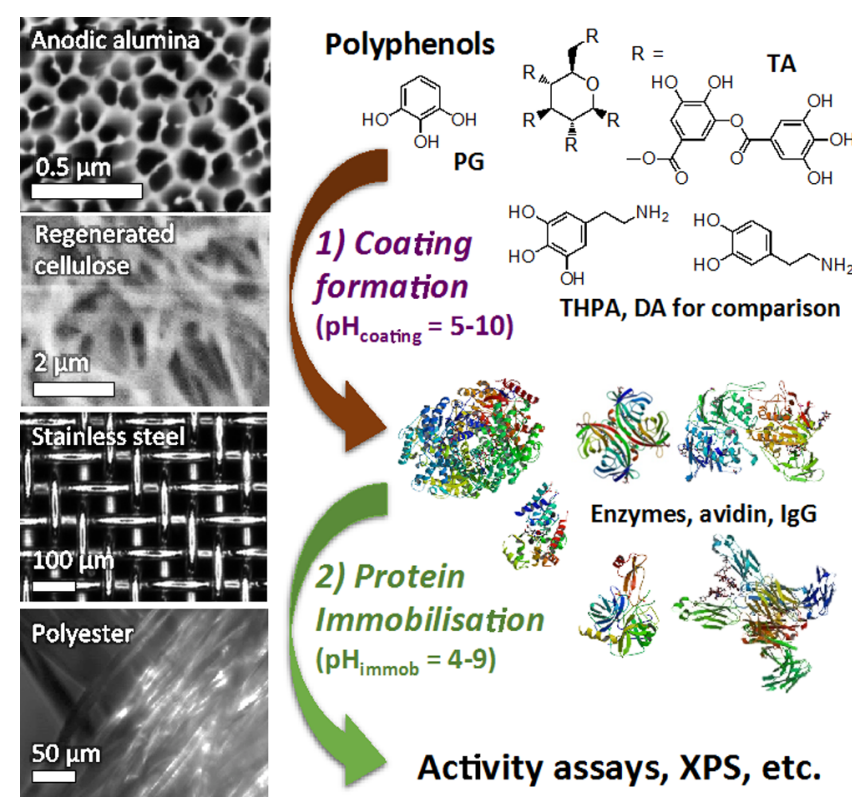

Figure 1. Overall scheme of (1) coating with TA, pyrogallol (PG), dopamine (DA), and 3,4,5-trihydroxyphenethylamine (THPA) precursors, followed by (2) immobilization of proteins. On the left are the images of the different material supports used: nanoporous anodic alumina and regenerated cellulose (SEM), 316 steel wire mesh and polyester fabric (optical microscopy). The proteins used are indicated by their structures catalogued in the protein data bank: 1XZW (phosphatase), 1MTN (chymotrypsin), 1I10 [lactate dehydrogenase (LDH)], 1HCH (HRP), 1HZH (IgG), and 2AVI (avidin).

characterization, we also found that the chemical nature of the polyphenol coatings and activity of proteins immobilized on them may depend on the processing $\mathrm{pH}$. In particular, our results demonstrate the importance of optimizing the immobilization conditions directly for activity, rather than the conventional foci on coating thickness and immobilized protein amount (i.e., protein loading). We also assessed the contributions of catechols and galloyls to the surface coupling of proteins to help distinguish the chemical properties of polyphenol coatings and pDA. We further made initial characterization studies on the polyphenol extracts for coating formation by HPLC and ESI-MS to gain insight into functionalization chemistry. Finally, we showed that low-cost polyphenol extracts from different plant species of even intermediate purities could also form effective coatings for immobilization, thus further demonstrating wide applicability of polyphenol coatings for biofunctionalization.

\section{RESULTS AND DISCUSSION}

\subsection{Activities of Proteins Immobilized by Polyphenol} Coatings. We focused on TA and PG to form pTA and pPG coatings, respectively, because these incorporate only trihydroxybenzene functional moieties and may be considered prototypical polyphenol coatings (Figure 1). In contrast, other polyphenols (e.g., catechins) present a number of phenols, heterocyclic groups, as well as catechols (dihydroxyphenyls), the latter of which is shared by "conventional" pDA coatings. Initial experiments (Figure 2) used coatings formed at $\mathrm{pH} 7.8$, simply by immersion of material supports in aqueous buffers containing TA and PG. Cellulose (as nanoporous membranes with $0.45 \mu \mathrm{m}$ pore size) and steel (as wire meshes) were chosen to illustrate material diversity and because of current 
" Phosphatase Chymotrypsin" HRP ${ }^{-}$LDH
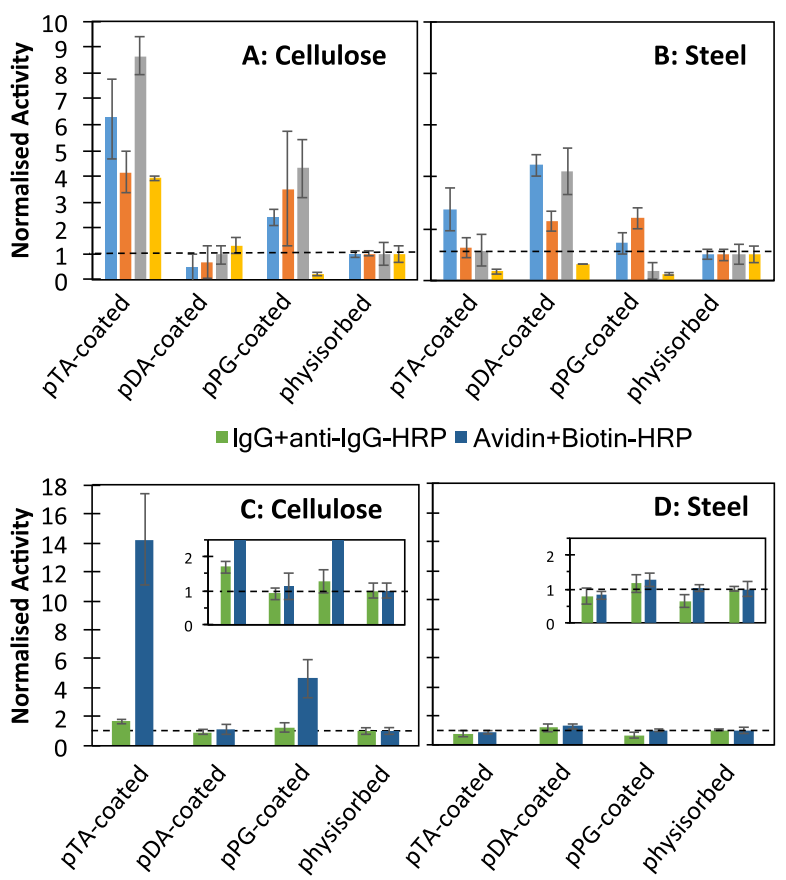

Figure 2. Relative activities of enzymes immobilized on pTA-, pDA-, and pPG-coated cellulose (A) and steel (B). The data are normalized to the activities of physisorbed proteins (dotted lines). The activities of biorecognition proteins IgG and avidin on cellulose (C) and steel (D) were characterized by secondary binding with antilgG-HRP and biotinylated-HRP. The activities of physisorbed phosphatase, chymotrypsin, HRP, LDH, IgG+anti-IgG-HRP, and avidin+biotinHRP are $80,2.1,2.1,0.5,13$, and $3.8 \mathrm{nmol} \cdot \mathrm{min}^{-1} \cdot \mathrm{m}^{-2}$ on cellulose and $192,3.1,0.1,0.7,37$, and $2.3 \mathrm{nmol} \cdot \mathrm{min}^{-1} \cdot \mathrm{m}^{-2}$ on steel, respectively. See Table S1 and Figure S5 for all specific activity values. All results were obtained from triplicates or more repeats. The error bars indicate \pm 1 SD.

limitations in functionalizing these common materials. ${ }^{45-48}$ Successful coating was confirmed by the appearance of a deep coloration in silver staining and by XPS (characterized by $\mathrm{C} 1 \mathrm{~s}$ intensity increase and/or coating thickness: Figures S1-S4). Where feasible, coatings were also verified by a change in the water contact angle (Figure S1). This general procedure gave coatings that were a few nanometers thick (see Section 2.2). Proteins were subsequently immobilized simply by the immersion of coated samples in an aqueous protein solution (see the Experimental in the Supporting Information).

Figure 2 shows that activities obtained on pTA and pPG coatings were higher in many cases than obtained by $\mathrm{pDA}$ (formed at the reported $\mathrm{pH} 8.5$ optimum) ${ }^{26}$ and physisorption. The proteins chosen-acid phosphatase, chymotrypsin, $\mathrm{HRP}$, and LDH, immunoglobulin G (IgG) and avidin-span diverse isoelectric points ( $\mathrm{pI}$ from 5 to 9), molecular weights (44-160 kDa), structural typologies (globular to multidomain), and molecular functions (from catalysis to protein binding). The area-specific activities of samples with immobilized enzymes (i.e., "immobilized activities") were quantified using typical absorbance enzyme assays adapted to solid samples (Scheme S1 and Supporting Information). Immobilized activities for IgG and avidin were compared with the enzymes through HRP assays after secondary binding to HRP-functionalized secondary antibodies (antiIgG-HRP) and HRP-biotin, respectively. To aid comparison, all results were normalized by the activities obtained by physisorption on uncoated controls.

On pTA-coated cellulose, activities of avidin, HRP, and phosphatase were ca. 14-, 8.5-, and 6.2-times higher than immobilization by physisorption (e.g., immobilized activity of $499 \mathrm{nmol} \cdot \mathrm{min}^{-1} \cdot \mathrm{m}^{-2}$ for phosphatase, equivalent to ca. $1.0 \mathrm{mg}$. $\mathrm{m}^{-2}$ active enzymes; even higher activities are possible-see Section 2.2). Activities of chymotrypsin and $\mathrm{LDH}$ were $\sim 4$ times higher than physisorption. In comparison, the immobilized activities on PPG were lower but still 2.5 to 5 -fold higher than the physisorption controls for all proteins except $\mathrm{LDH}$ and IgG. pDA performed no better than physisorption under the present conditions. For IgG, only pTA was able to increase the immobilized activity on cellulose (by $\sim 1.5$-times).

On steel (Figure 2B,D), pTA and pPG were observed to improve the immobilized activity by 2.5 -fold compared to physisorption for both phosphatase and chymotrypsin. Although chymotrypsin activities on $\mathrm{pDA}$ were comparable, immobilized activities of both phosphatase and HRP on pDA were actually higher than on pTA. However, although the benefit of pTA on steel over pDA and physisorption appears less dramatic, we note that the measured activities of HRP coupled to IgG and avidin were already orders of magnitude higher than for HRP physisorbed alone (respectively, 37 and 2.3 vs $0.1 \mathrm{nmol} \cdot \mathrm{min}^{-1} \cdot \mathrm{m}^{-2}$ ).

We also performed additional experiments with the oxidative enzyme laccase, which show 1.7-times higher immobilized activities using pTA than by physisorption on the cellulose (Figure S6). Furthermore, we have previously shown that thermolysin immobilization on glass and graphitic carbon surfaces by pTA and pPG was similarly effective as by pDA using the current (unoptimized) conditions (see below). ${ }^{35}$ At the same time, the higher immobilized activities obtained with pTA versus pPG coatings could indicate that the branched multivalent structure of TA could improve coupling or activity retention (see further discussion in Section 2.3). Overall, we show that cross-linked polyphenol coatings are highly versatile for protein functionalization on diverse materials, including in nanoporous structures. Nonetheless, we emphasize that Figure 2 shows only relative activity values. For example, although the activity of phosphatase immobilized via pTA was ca. 6.0-times that by physisorption on cellulose, while it is 2.7-times on steel, the absolute specific activities were similar (499 vs $527 \mathrm{nmol}$. $\mathrm{min}^{-1} \cdot \mathrm{m}^{-2}$ on cellulose and on steel; see Figure S5) because the physisorbed phosphatase baseline was higher on steel than on cellulose $\left(192\right.$ vs $\left.80 \mathrm{nmol} \cdot \mathrm{min}^{-1} \cdot \mathrm{m}^{-2}\right)$. However, there are significantly different activities in some cases for enzymes immobilized on the same coating but on different supports (e.g., HRP and LDH on pTA). The possibility of functional differences for the same type of polyphenol coating is further explored below.

2.2. Factors Influencing Activity of Proteins Immobilized on Polyphenol Coatings. The $\mathrm{pH}$ is expected to strongly influence coating properties because it controls polyphenol oxidation. We first characterized the effects of the $\mathrm{pH}$ used for coating treatment $\left(\mathrm{pH}_{\text {coating }}\right)$ on the subsequent immobilized protein activity on different materials (Section 2.2.1) and then examined its relationships with the quantity and quality of the polyphenol deposited as well as the amount of proteins immobilized (Section 2.2.2). We then examined the effects of $\mathrm{pH}_{\text {immob}}$, the $\mathrm{pH}$ used for protein immobilization (Section 2.2.3). 
2.2.1. Effect of $\mathrm{pH}$ during Coating Treatment $\left(\mathrm{pH}_{\text {coating }}\right)$. Given the encouraging results for pTA shown in Figure 2, we focused on comparing its use with the popular pDA. In addition to cellulose and steel, we included polyester fabric and nanoporous alumina $(0.2 \mu \mathrm{m}$ pore size $)$ to highlight the utility of pTA on additional polymeric and oxide materials that have not yet been demonstrated for polyphenol coatings. As example, we picked acid phosphatase from the earlier panel of proteins because the enzyme is widely used and may be conveniently assayed. ${ }^{49} \mathrm{We}$ studied $\mathrm{pH}_{\text {coating }} 5-10$ to approximately span the first phenolic $\mathrm{p} K_{\mathrm{a}}$ of $\mathrm{TA}$ (7.7) and $\mathrm{DA}$ (10.6) as well as $\sim 2 \mathrm{pH}$ below them-the lower range down to which coatings are expected to form. ${ }^{29,50}$

Figure 3 shows that the immobilized enzyme activity depended significantly on $\mathrm{pH}_{\text {coating }}$ as well as the underlying

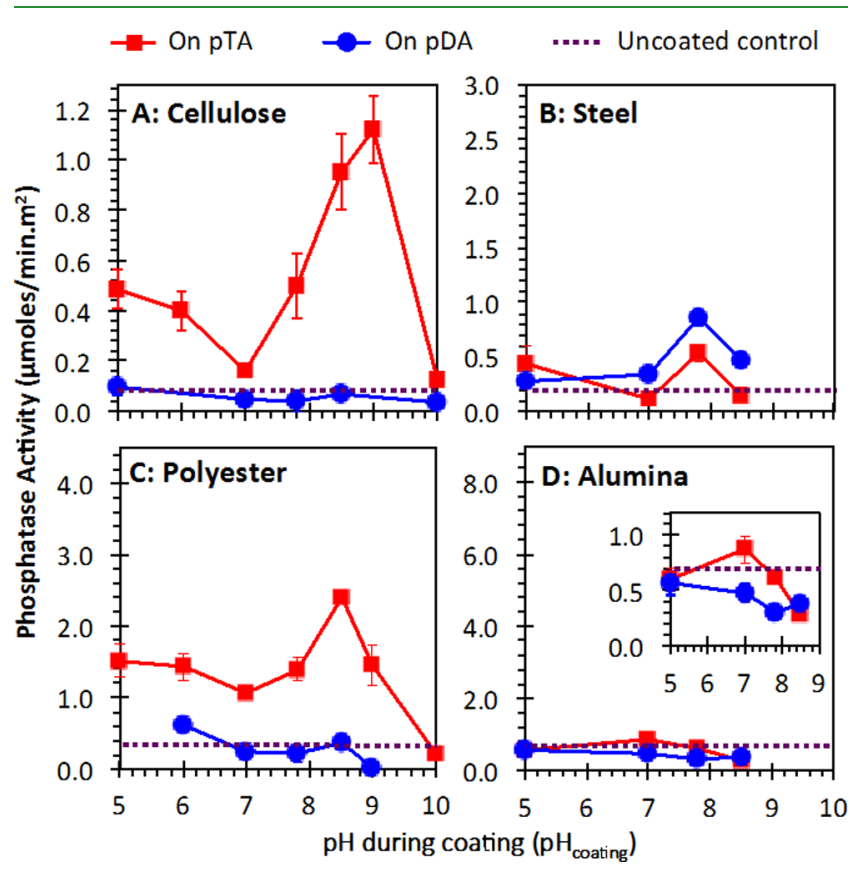

Figure 3. Effect of $\mathrm{pH}_{\text {coating }}$ on immobilized phosphatase activities for pTA- and pDA-coated (A) cellulose, (B) steel, (C) polyester, and (D) alumina. The plots are scaled to match side-to-side the activities obtained by physisorption on uncoated materials (dotted lines). The peak activities on pTA are $1.1,0.5,2.4$, and $0.8 \mu \mathrm{mol} \cdot \mathrm{min}^{-1} \cdot \mathrm{m}^{-2}$ on pTA-coated cellulose, steel, polyester, and alumina, respectively (corresponding to ca. 2.2, 1.1, 4.8, and $1.7 \mathrm{mg} \cdot \mathrm{m}^{-2}$ of active phosphatase; see the Supporting Information). All results are obtained from triplicates or more repeats. The error bars indicate $\pm 1 \mathrm{SD}$.

type of material support. Overall, by varying $\mathrm{pH}_{\text {coating, we could }}$ improve upon our initial results for pTA (Figure 2) to obtain optimal immobilized phosphatase activities that ranged from a high of 13-times over physisorption on cellulose to 1.3-times on alumina. The maximum activities-1.1, 0.5, 2.4, and 0.8 $\mu \mathrm{mol} \cdot \mathrm{min}^{-1} \cdot \mathrm{m}^{-2}$ on $\mathrm{pTA}$-coated cellulose, steel, polyester and alumina, respectively-correspond to approximately $2.2,1.1$, 4.8 , and $1.7 \mathrm{mg} \cdot \mathrm{m}^{-2}$ of active phosphatase (i.e., $220,110,480$, and $170 \mathrm{ng} \cdot \mathrm{cm}^{-2}$; see the Supporting Information for calculations).

Interestingly, the immobilized activities on the pTA-coated cellulose and polyester both showed overall peaks around $\mathrm{pH}_{\text {coating }} \approx 8.5$ (statistically similar to activity at $\mathrm{pH} 9$ on cellulose), which is significantly more basic than the range of $\mathrm{pH}$ previously reported for optimum coating formation $(\mathrm{pH}$
$6-7.8) .^{26,27,29}$ In fact, on cellulose and polyester, there is a relative decrease in immobilized activities around the $\mathrm{pH}_{\text {coating }}$ identified with optimal coating formation (but still significantly higher than the physisorbed activities). In contrast, on pTAtreated steel and alumina, the highest activities were observed at $\mathrm{pH}_{\text {coating }} 7.8$ and 7 , respectively $\left(\mathrm{pH}_{\text {coating }}>8.5\right.$ not shown because preliminary tests showed negligible activities on steel and etching of alumina).

For pDA, some increase in immobilized activity is observed at $\mathrm{pH}_{\text {coating }}=8.5$, the optimum for coating formation, for 3 out of 4 underlying materials tested-cellulose, polyester, and alumina. However, the activities were overall at or below the physisorption controls. The exception is on steel, for which the activity showed a peak at $\mathrm{pH}_{\text {coating }}=7.8$ that was actually $\sim 50 \%$ higher than on pTA and the physisorption control.

We also investigated some cases of using pPG, as well as coatings formed from the DA analog THPA (i.e., pTHPA coatings $)^{23}$ that have both the primary amine of DA and the trihydroxybenzene of TA and PG (Figure S7). On pPG-treated cellulose, the optimum $\mathrm{pH}_{\text {coating }}$ (8.5) was similar to that for pTA (9), but the activity was lower (2.4 vs 13-times of physisorption). On pPG-treated alumina, the activities were overall similar to pTA. However the optimum $\mathrm{pH}_{\text {coating }}$ was shifted to a more basic 8.5 . In contrast, the activity trends for pTHPA-coated cellulose and alumina resembled those obtained for pDA: on cellulose, lower activities than pTA/ pPG were obtained and there is an increase in activities around $\mathrm{pH}_{\text {coating }}=7.8-8.5$; on alumina, the activity also tended to decrease as $\mathrm{pH}_{\text {coating }}$ increased.

Overall, the current results show that even higher immobilized activities than obtained from the initial measurements of Section 2.1 could be obtained on polyphenol coatings, but the optimum $\mathrm{pH}_{\text {coating }}$ for immobilized activity may vary, depending on the polyphenol species and the underlying material, from the $\mathrm{pH}_{\text {coating }}$ anticipated from coating studies. The high activities obtained for the nanoporous cellulose and alumina samples also show that the thin coatings (see Section 2.2.2 below) were suitable for protein functionalization in these confined nanostructures. The relative similarities in $\mathrm{pH}_{\text {coating }}$ activity trends shared by pTA and pPG and by $\mathrm{pDA}$ and pTHPA further suggest that the chemical interactions enabled by the primary amine found only in THPA and DA could determine the contrasting performance in protein immobilization observed between $\mathrm{pDA}$ and the polyphenol coatings.

2.2.2. Effects of $\mathrm{pH}_{\text {coating }}$ on Amounts of Coating Deposited and Proteins Immobilized. We used XPS to further characterize phosphatase immobilization on the cellulose and alumina, as example nanoporous materials with divergent properties (Figure 4). On cellulose, the amount of enzyme immobilized was characterized by the change in nitrogen composition ( $\mathrm{N} \%$ ) because $\mathrm{N}$ is abundant in proteins and is not found in cellulose. The changes in carbon composition ( $\mathrm{C} \%$ ) and $\mathrm{N} \%$ were used to characterize the depositions of the underlying pTA and pDA layers, respectively because TA has a higher $\mathrm{C} / \mathrm{O}$ ratio than cellulose (1.65 vs 1.4) and pDA incorporates N. On alumina, we were able to use the Al $2 \mathrm{p}$ signal of the underlying support to directly characterize the thickness of both the coating and protein layers.

High protein loading is often a focus of past studies on protein immobilization. ${ }^{16}$ However, Figure 4 shows that the optimum $\mathrm{pH}_{\text {coating }}$ for high amounts immobilized (i.e., high 


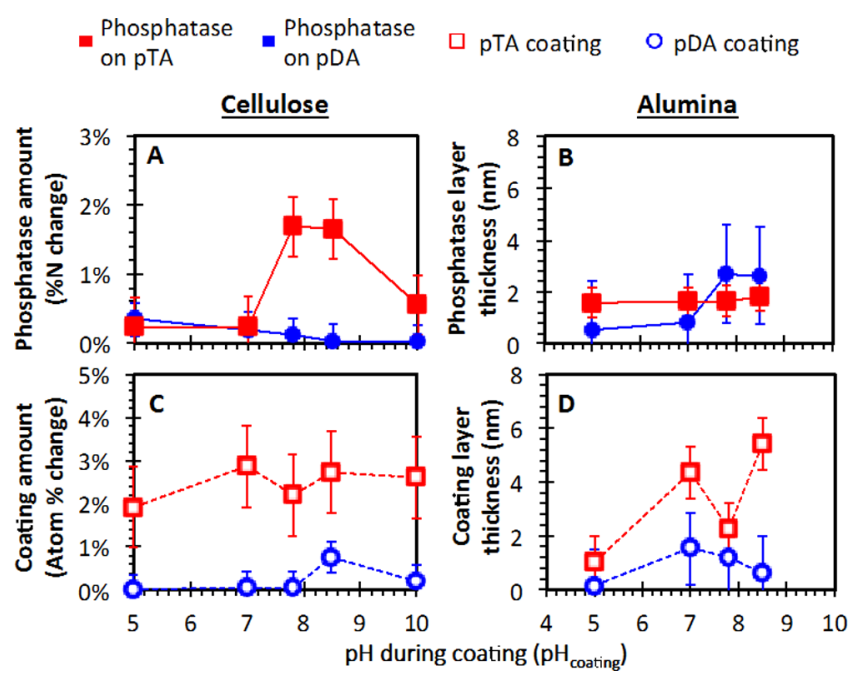

Figure 4. XPS data characterizing the effect of varying $\mathrm{pH}_{\text {coating }}$ on the amounts of phosphatase immobilized $(\mathrm{A}, \mathrm{B})$ and coating deposited $(C, D)$ on cellulose $(A, C)$ and alumina $(B, D)$. In $(C)$, the amounts of pTA and pDA coatings on cellulose are indicated by the increases in $\% \mathrm{C}$ and $\% \mathrm{~N}$, respectively. The uncertainties are indicated by $\pm 1 \mathrm{rms}$ deviation calculated for each set of data (SD not used because it was not feasible to repeat measurements for every condition by XPS).

loading) can be significantly different from the optimum for high immobilized activities. For example, on the pTA-coated cellulose, while the amounts immobilized at $\mathrm{pH}_{\text {coating }}=7.8$ and 8.5 were similar (Figure $4 \mathrm{~A}$ ), the activity at $\mathrm{pH}_{\text {coating }}=8.5$ was double that at $\mathrm{pH}_{\text {coating }}=7.8$ (Figure 3 ). The amounts immobilized at $\mathrm{pH}_{\text {coating }}=5$ and 7 were also similar, but the enhancement over physisorption was much less at $\mathrm{pH}_{\text {coating }}=7$ than at the more acidic coating condition (Figure 3 ). In addition, roughly the same coating thickness was observed over the entire $\mathrm{pH}_{\text {coating }}$ range from 5 to 10 (Figure 4C).

Differences between the optimum $\mathrm{pH}_{\text {coating }}$ for protein immobilization, coating deposition, and protein activity were also observed on pTA-coated alumina. However, the detailed trends are different, with pTA thickness generally increasing from 1 to $5.5 \mathrm{~nm}$ as $\mathrm{pH}_{\text {coating }}$ increased from 5 to 8.5 (Figure $4 \mathrm{D})$, whereas the amount of immobilized protein remained relatively constant (Figure 4B). There is no apparent correlation between the immobilized amount and the measured activity, which reached a maximum at $\mathrm{pH}_{\text {coating }}=7$ (Figure 3D).

Differences between the amounts of proteins immobilized and activities are not surprising, given the many potential causes for reduced activity-covalent reaction of essential residues, blocked access to active sites, denaturation or rigidification by (multiple) surface attachments, and so forth. ${ }^{13,16,18}$ However, because only $\mathrm{pH}_{\text {coating }}$ was varied and not the $\mathrm{pH}$ experienced by the enzyme during immobilization ( $\mathrm{pH}$ 5.2), and the thickness of pTA coatings was also not correlated with the immobilized activities, the current results indicate that $\mathrm{pTA}$ deposited at different $\mathrm{pH}_{\text {coating }}$ values may have significant chemical differences. This could then give rise to different amounts of phosphatase immobilized and also to different levels of activity retention.

Indeed, silver staining of pTA on cellulose showed significant variation in coloration over different $\mathrm{pH}_{\text {coating }}$ values (Figure S8). However, differences in the reductive ability of pTA suggested by staining is only partially correlated with immobilized activity-although a deep coloration was observed at $\mathrm{pH}_{\text {coating }} 8.5$ (the condition with high activity), the coloration was similarly light for $\mathrm{pH}_{\text {coating }} 7$ and 9 (one condition has a lower than and the other a similar activity as at $\mathrm{pH}_{\text {coating }} 8.5$ ).

XPS $\mathrm{C}$ 1s chemical shift measurements show different proportions of carbon bonding within pTA formed at different $\mathrm{pH}_{\text {coating }}$ values (Figures S9 and S10). Coatings formed at the $\mathrm{pH}_{\text {coating }}$ optimum for activity on cellulose (8.5) are characterized by relatively more $\mathrm{C}-\mathrm{C}$, more $\mathrm{C}-\mathrm{O}$, and fewer $\mathrm{C}=\mathrm{O} / \mathrm{O}-\mathrm{C}-\mathrm{O}$ bonds compared to other $\mathrm{pH}_{\text {coating }}$ conditions. Interestingly, at $\mathrm{pH}_{\text {coating }} 7$ for which the immobilized activity is depressed, even more $\mathrm{C}-\mathrm{O}$ bonds but fewer $\mathrm{C}-\mathrm{C}$ bonds were observed. A decreased $\mathrm{C}=\mathrm{O}$ content could indicate fewer reactive quinones. Additional $\mathrm{C}-$ $\mathrm{C}$ and $\mathrm{C}-\mathrm{O}$ bonds could respectively indicate more aryl-aryl and diaryl ether linkages between galloyl groups, both consistent with more cross-linked coatings. $\mathrm{C}-\mathrm{O}$ bonds could, however, also indicate unreacted hydroxyphenyls. Thus, coatings that are more cross-linked but with fewer remaining reactive groups (needed for covalent linkages with proteins) might actually lead to increased activity retention. Further chemical structure characterization of the thin coatings is challenging. The current chemical shift and silver staining characterization nonetheless show that pTA formed at different $\mathrm{pH}_{\text {coating }}$ values is not chemically equivalent. The most biofunctional coatings may actually be less reactive.

For pDAs, distinctly thicker coatings were obtained on cellulose around the expected optimum $\mathrm{pH}_{\text {coating }} 8.5^{26}$ (Figure $4 \mathrm{C}, \mathrm{D})$. However, little, if any, phosphatase was immobilized at this condition (Figure 4A). This lack of immobilization for phosphatase may also apply to other selected proteins and could help explain the occasional report that certain cells may not adhere well directly on pDA coatings. ${ }^{51}$ In contrast, a higher activity equal to the physisorption control was measured at $\mathrm{pH}_{\text {coating }}=5$ (Figure $3 \mathrm{~A}$ ), where essentially no $\mathrm{pDA}$ was formed but some proteins were immobilized (Figure 4A,C). Thus, the observed protein immobilization and activities on pDA-coated cellulose at more acidic $\mathrm{pH}_{\text {coating }}$ were likely due entirely to adsorbed proteins. On alumina, a high amount of immobilized phosphatase was observed at $\mathrm{pH}_{\text {coating }}=7.8$ and 8.5 (Figure 4B), which was correlated with the deposition of pDA (Figure 4C). The amounts immobilized were even higher than on pTA but the activities were lower (Figure 3D). In fact, like on cellulose, the highest activity was observed at $\mathrm{pH}_{\text {coating }}=$ 5 when essentially no pDA was deposited and the activity could again be attributed to physisorbed proteins.

The XPS chemical shift data for pDA-treated cellulose and anodic alumina generally show higher $\mathrm{C}-\mathrm{C}$ and lower $\mathrm{C}-\mathrm{O}$ (anodic alumina can contain $\mathrm{C}-\mathrm{O}$ because it is prepared in an organic acid). However differences between pDA formed at different $\mathrm{pH}_{\text {coating }}$ values could not be clearly distinguished because of the relatively low signals of the thin layers deposited. Nonetheless, like for pTA, thicker pDA coatings do not imply more proteins immobilized.

2.2.3. Effects of $p H$ during Protein Immobilization $\left(\mathrm{pH}_{\text {immob }}\right)$. Focusing on $\mathrm{pTA}$, we investigated the $\mathrm{pH}$ used during protein immobilization $\left(\mathrm{pH}_{\text {immob }}\right)$, while maintaining $\mathrm{pH}_{\text {coating }}$ at 7.8 (matching the original report of $\left.\mathrm{pTA}\right){ }^{25}$ $\mathrm{pH}_{\text {immob }}$ may modify the chemical nature of $\mathrm{pTA}$, the protein's net charge and conformation, as well as the interactions between pTA and protein during immobilization. We therefore studied a range of $\mathrm{pH}_{\text {immob }}=3.8-8$, centered around the 
isoelectric point of phosphatase $\left.\left(\mathrm{pI}_{\text {phosphatase }}=5.2\right)\right)^{52}$ while covering the first $\mathrm{pK}_{\mathrm{a}}$ of TA (7.7). Overall, we observed a more general correspondence between the trends in immobilized activity and phosphatase immobilization than when $\mathrm{pH}_{\text {coating }}$ was varied (Section 2.2.2). However significant differences remained.

On cellulose, we found similarly high activities over $\mathrm{pH}_{\text {immob }}$ $=3.8-5.2\left(\sim 0.33 \mu \mathrm{mol} \cdot \mathrm{min}^{-1} \cdot \mathrm{m}^{-2}\right.$, corresponding to $\sim 0.6 \mathrm{mg}$. $\left.\mathrm{m}^{-2}\right)$, which then progressively decreased as $\mathrm{pH}_{\text {immob }}$ increased to 8 (down to $\sim 0.1 \mu \mathrm{mol} \cdot \mathrm{min}^{-1} \cdot \mathrm{m}^{-2}$ : Figure $5 \mathrm{~A}$ ). The high

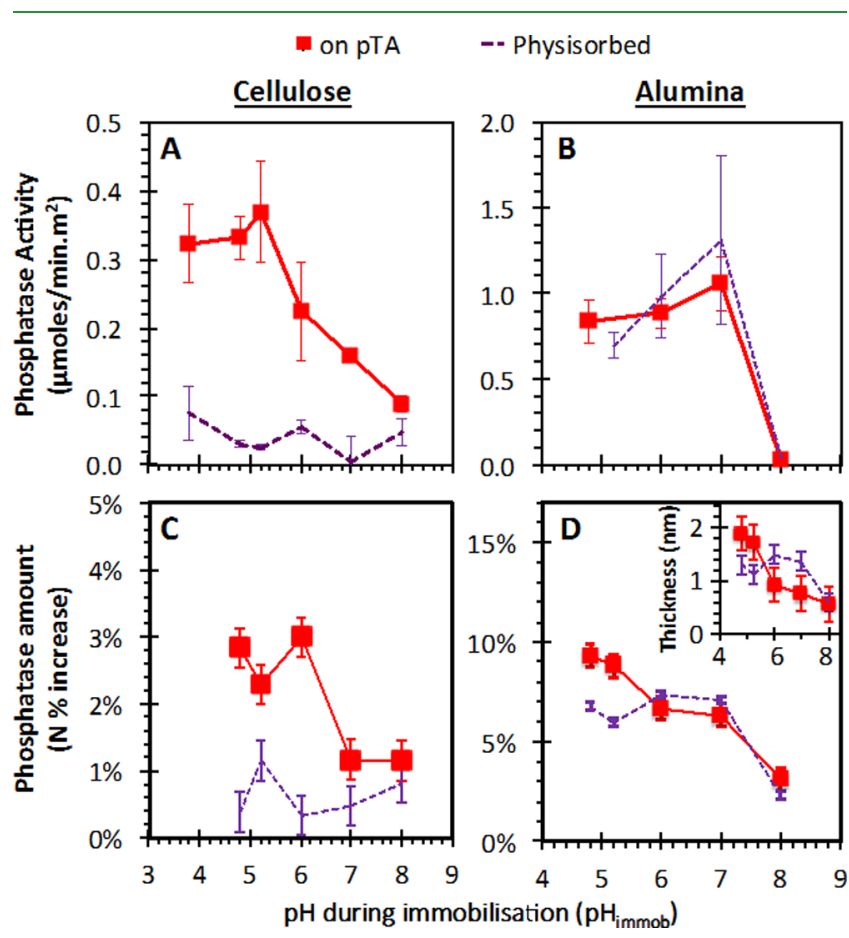

Figure 5. Effect of $\mathrm{pH}_{\text {immob }}$ on phosphatase activity $(\mathrm{A}, \mathrm{B})$ and amount of proteins immobilized $(C, D)$ on cellulose $(A, C)$ and alumina $(B, D)$. Immobilization amounts are indicated by the $\mathrm{N} \%$ increase because of the addition of phosphatase. All activity results obtained from triplicates or more repeats. The error bars for activity indicate $\pm 1 \mathrm{SD}$. Those for XPS measured $\mathrm{N} \%$ are indicated by $\pm 1 \mathrm{rms}$ deviation calculated for each set of data.

activities over acidic $\mathrm{pH}_{\text {immob }}$ were matched by high amounts of immobilized phosphatase, and there was also a drop in immobilization as $\mathrm{pH}_{\text {immob }}$ increased (Figure 5C). However, the drop was observed only from a less acidic $\mathrm{pH}_{\text {immob }} 6$, and it occurred as a relatively rapid transition between $\mathrm{pH}_{\text {immob }} 6$ and 7.

On alumina, we also saw higher amounts of proteins immobilized by pTA at more acidic $\mathrm{pH}_{\text {immob }}$ (Figure 5D), but the transition from low to high $\mathrm{pH}_{\text {immob }}$ was more gradual. The average thickness of the phosphatase layer decreased from $\sim 2$ to $\sim 0.6 \mathrm{~nm}$ as $\mathrm{pH}_{\text {immob }}$ increased from 4.8 to 8 (the low thickness indicates submonolayers with gaps between immobilized proteins). Interestingly, over the less acidic range of $\mathrm{pH}_{\text {immob }} 6-8$, similar amounts of proteins could already be immobilized by physisorption on alumina without pTA, while more phosphatase could be immobilized on pTA-coated alumina only at $\mathrm{pH}_{\mathrm{immob}}<6$. In comparison, there is a clear maximum in activities at $\mathrm{pH}_{\text {immob }}=7$ not matched by the decrease in immobilization. It also appears unusual that a very low activity was observed at $\mathrm{pH}_{\text {immob }} 8$, even though there was a nonnegligible amount of immobilization.

We investigated the conformational state of phosphatase immobilized on alumina by solid-state ${ }^{13} \mathrm{C}$ CPMAS NMR. First, measurement of phosphatase physisorbed at $\mathrm{pH}_{\text {immob }} 8$, at which there was little activity, shows a protein fingerprint region characterized mainly by reduced intensities from the backbone carbonyl (160-185 ppm) and $\mathrm{C}_{\alpha}(40-70 \mathrm{ppm})$ regions, which indicate possible structural disorder (compare Figure $6 \mathrm{~A}, \mathrm{C}$ ). In contrast, the spectrum from physisorption at $\mathrm{pH}_{\text {immob }} 7$, the optimal $\mathrm{pH}_{\text {immob }}$ for high activity, shows many features corresponding to the reference spectrum (compare Figure 6A,B). Distinct patterns for aliphatic, aromatic, guanidine zeta-carbon in Arg sidechains, and backbone carbonyls (0-80 ppm, 110-150 ppm, 160 ppm, and 160$185 \mathrm{ppm}$, respectively) are clearly observed. Two distinct low- ${ }^{13} \mathrm{C}$-frequency shoulder peaks from the Ile side chains $(10-20 \mathrm{ppm})$ also indicate high structural order. Analogous results were observed for phosphatase immobilized on pTAcoated alumina, with distinct fingerprint signatures for active proteins measured for the $\mathrm{pH}_{\text {immob }}=7$ sample, and reduced peak features for the $\mathrm{pH}_{\text {immob }}=8$ sample (Figure 6D,E).

Samples at $\mathrm{pH}_{\text {immob }}<7$ were not analyzed because relatively high activities similar to the $\mathrm{pH}_{\text {immob }}=7$ condition were already observed. We were also unable to perform solid-state NMR measurements on cellulose samples because polysaccharides give interfering peaks in the ${ }^{13} \mathrm{C}$ protein fingerprint region. Nonetheless, we observe that the activity of phosphatase immobilized at $\mathrm{pH}_{\text {immob }} 8$ on pTA-coated cellulose, in contrast to alumina, is not negligible ( 0.1 vs $0.03 \mu \mathrm{mol} \mathrm{min}-1 \mathrm{~m}^{-2}$ ), even though the amount immobilized is less than on pTA-coated alumina ( 1.3 vs $3 \% \mathrm{~N})$. Therefore, although pTA, and by extension polyphenol coatings, generally enables effective protein immobilization, specific materials could affect the conformational state of immobilized proteins and the optimization of immobilization.

To corroborate the abovementioned observations, we also immobilized another common enzyme, chymotrypsin, on pTA-coated alumina (Figure S12). An optimum in immobilized activities at an intermediate $\mathrm{pH}_{\text {immob }}$ was also observed, and the activity also decreased toward basic $\mathrm{pH}_{\text {immob }} 8$. However, there was a relative drop in activities at acidic $\mathrm{pH}_{\text {immob }} 5$ such that an optimum emerged at $\mathrm{pH}_{\text {immob }} 6$ for chymotrypsin on pTA that is much more distinct than the optimum for phosphatase (at $\mathrm{pH}_{\text {immob }} 7$ ). Moreover, the immobilized chymotrypsin activities were generally much higher than obtained by physisorption. This was 4-times higher than physisorption at the optimal $\mathrm{pH}_{\text {immob }}$ (also 6), and the lowest activities at $\mathrm{pH}_{\text {immob }} 5$ and 8 were still higher than the highest obtained by physisorption.

Chymotrypsin has a basic $\mathrm{pI}_{\text {chymotrypsin }} \approx 10$, in contrast to the acidic $\mathrm{pI}_{\text {phosphatase }} \approx 5.2$. Hence, the activity optimum observed around a similar $\mathrm{pH}_{\text {immob }} 6-7$ for both proteins might indicate a nonelectrostatic effect specific to alumina. On the other hand, the drop in activities from intermediate to basic $\mathrm{pH}_{\mathrm{immob}}$ on both pTA-coated alumina and cellulose could indicate a behavior particular to immobilization on pTA. The step-like transition in the amounts immobilized on pTA-coated cellulose between $\mathrm{pH}_{\text {immob }} 6$ and 7 could also suggest differing contributions to pTA-protein interactions at acidic and neutral/basic $\mathrm{pH}_{\text {immob }}$. Overall, straightforward application of pTA for protein immobilization can result in equal or higher activities than possible by physisorption but optimization of 


\section{A: Phosphatase reference}

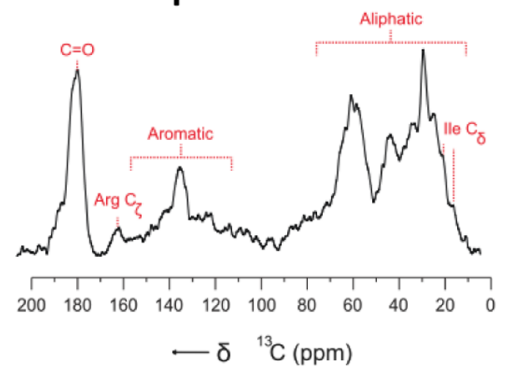

\section{B: Physisorbed ( $\left.\mathrm{pH}_{\text {immob }} 7\right)$}

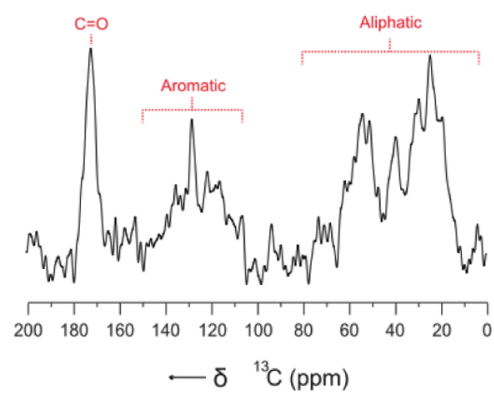

\section{D: Immobilized on PTA $\left(\mathrm{pH}_{\text {immob }} 7\right)$}

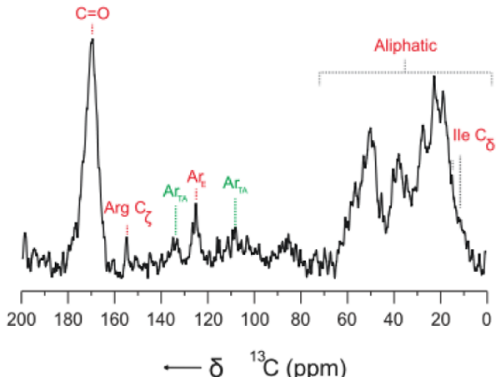

\section{C: Physisorbed $\left(\mathrm{pH}_{\text {immob }} 8\right)$}

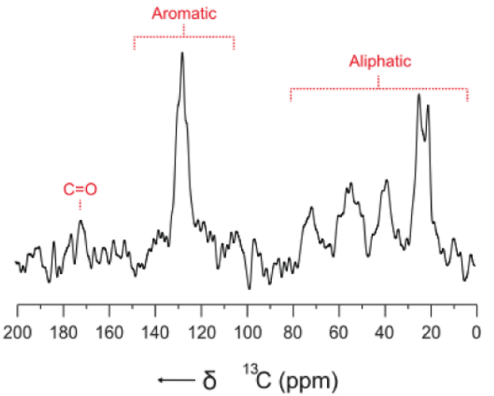

\section{E: Immobilized on pTA}

$$
\left(\mathrm{pH}_{\mathrm{immob}} 8\right)
$$

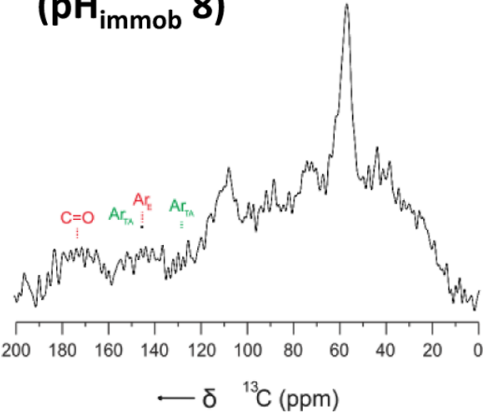

Figure $6 .{ }^{13} \mathrm{C}$ CPMAS spectra of lyophilized phosphatase (A), and the enzyme physisorbed on alumina at $\mathrm{pH}_{\text {immob }}=7$ (B) and 8 (C), as well as on pTA-coated alumina after immobilization at $\mathrm{pH}_{\text {immob }}=7$ (D) and $8(\mathrm{E})$. The fingerprint regions from the enzyme and those from pTA are labeled in red and green, respectively (see Figure S11 for pTA reference).

$\mathrm{pH}_{\text {immob }}$ and hence activity may be needed to compensate for material- and protein-specific effects. Higher activities on pTA appear to be favored by neutral and lower $\mathrm{pH}_{\text {immob}}$, at least for the current enzyme-material systems tested.

\subsection{Polyphenols from Different Sources and Purities.} The number of galloyl substitutions and the degree that TA is hydrolyzed may vary depending on the plant source and extract purification process ${ }^{53,54}$ and hence may impact the functionality of the pTA formed. We therefore compared a set of commercially available TA for protein immobilization: (i) the TA used in earlier sections (>95\% mixture of tea leaf, oak bark, and grape stem extracts), (ii) tara pod TA extracts (94\%), and (iii) and (iv) gallnut TA extracts from Rhus chinensis (81 and 93\%). Experiments were performed on nanoporous cellulose for which physisorption is not effective.

Figure 7 shows that pTA formed from both the mixture and gallnuts at different grades were able to achieve high immobilized phosphatase activities, while coatings from tara pods were much less effective. Results from the mixture and gallnut samples were statistically similar. Corresponding to Figure 3, higher immobilized activities were achieved at

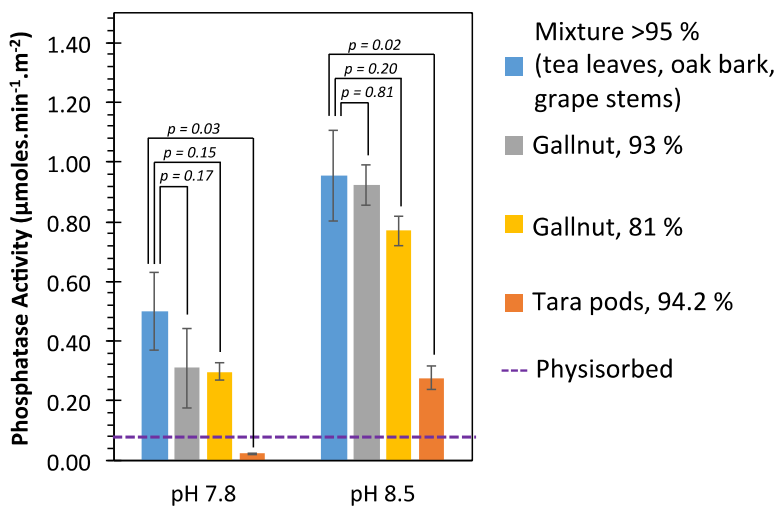

Figure 7. Immobilized phosphatase activities on pTA-coated cellulose. Coatings were formed using extracts from different sources and grades-mixture (tea leaves, oak bark, grape stems, >95\%), gallnuts from Rhus chinensis (81 and 93\%), and tara pods (94\%). All results obtained from triplicates or more repeats. The error bars indicate $\pm 1 \mathrm{SD}$. 
$\mathrm{pH}_{\text {coating }}=8.5$ than at $\mathrm{pH}_{\text {coating }}=7.8$ (respectively ca. 10 - and 4-times over physisorption). It therefore appears that some sources of polyphenol may be able to give more functional coatings than others, but moderately lower phenolic purity may nonetheless be sufficient.

Reverse-phase HPLC shows a distinct distribution of components for the tara pod TA sample, which mostly eluted at $<40 \%$ acetonitrile $(\mathrm{ACN})$ in a water $-\mathrm{ACN}$ gradient (Figure S13). In comparison, the mixed and gallnut samples gave components mainly eluting at $>40 \%$ ACN. This indicates the presence of fewer galloyl units in our tara pod TA. Correspondingly, in mass spectrometry (MS), the tara pod sample gave lower-molecular weight TAs (with 2-5 galloyls), while the mixed and gallnut samples both gave TA with four galloyls up to the often shown five-arm decagalloyl glucose structure (Figures S14 and S15). Interestingly, MS also shows that the samples were distinguished by different ranges of highmolecular weight species consistent with multiple TAs crosslinked through their galloyl arms that further exhibit methylations and/or quinones (e.g., Figure S16). These fragments are consistent with oligomers that characterize early stages of coating formation. In particular, we found in the tara pod sample a wider range of significantly more complex species with higher degrees of modification and numbers of glucose cores. Although the modifications could have been introduced by the MS ionization process, they clearly indicate differences in potential reactivities of the various plant sources. Thus, the low-enzyme activities on tara pod TA-treated cellulose may relate less to the size of the TAs, as also suggested by the effectiveness of pPG (Figure 2), and more to the reactivity of the tara pod TAs. This would further be consistent with results in Section 2.2.2, suggesting higher immobilized activities on pTA with only an intermediate number of reactive groups.

\section{DISCUSSION AND CONCLUSIONS}

We showed that polyphenol coatings may be applied to a range of common materials from cellulose to alumina and demonstrated the abilities of pTA and pPG coatings for immobilizing a panel of enzymes and proteins. Activities of enzymes immobilized on pTA can be more than an order of magnitude higher than those obtained on pDA on some materials. Especially, remarkable improvement over pDA was shown on both polyester and the polysaccharide cellulose. The favorable interaction with cellulose might be associated with polyphenol's natural affinity with glycoproteins that gives rise to the sensation of astringency. ${ }^{54}$

Use of the polyphenol coatings offers more choices of processing $\mathrm{pH}$ and material supports. In particular, the $\mathrm{pH}_{\text {coating }}$ was found to strongly influence the proportion of different chemical bonds in the polyphenol coating. This heavily influenced protein loading, which however was a poor indicator of final immobilized activity. In contrast, $\mathrm{pH}_{\text {coating }}$ producing coatings of intermediate reactivity appeared to promote high activity. In parallel, $\mathrm{pH}_{\text {immob }}$ was also shown to influence the final activity, in some cases because of surfaceinduced denaturation. While straightforward application of a standard polyphenol aqueous functionalization protocol may produce high activities, $\mathrm{pH}_{\text {coating }}$ and $\mathrm{pH}_{\text {immob }}$ were found to be convenient parameters to directly optimize for high activities.

Considering that proteins are relatively fragile biomolecules that may be denatured by surface interactions, the high activities measured (e.g., on the order of $1-5 \mathrm{mg} \cdot \mathrm{m}^{-2}$ active phosphatase) show that polyphenol coatings constitute an excellent material for biofunctionalization. The main chemical feature distinguishing polyphenol coatings compared to $\mathrm{pDA}$ appears to be the elimination of the amine group of DA. Moreover, coatings formed from even lower purity plant extracts may still be highly functional, which (further) points to the green chemistry potential of polyphenol coatings. While this study focused on polyphenol coatings a few nanometers thick, the results on nanoporous cellulose and alumina highlight the potential of such thin coatings for functionalizing nanostructures for which thicker layers could significantly alter the original nanostructure and intended application.

Although this report focused on demonstrating the general applicability of polyphenol coatings for biofunctionalization, we note that effective immobilization of the proteins studied are recognized to be important for a number of potential applications, including biocatalysis, biosensors, biofuel cells, and biomedicines. ${ }^{5,7,13}$ For example, immobilized antibodies, avidin, and HRP have obvious applications in biosensing and bionanotechnology. ${ }^{5,55}$ A number of applications ranging from biofuel cells to biosensing have been reported for sequestered laccase, ${ }^{56}$ and there had been early interest in commercializing laccase systems for industrial biocatalysis. ${ }^{57}$ Immobilized proteases may also be used for biosensing, ${ }^{3}$ and we have immobilized chymotrypsin for controlling and organizing selfassembly of nanostructures. ${ }^{6}$ Seen in the light of our current results on enabling high immobilized protein activity on diverse materials and the functional and cost advantages for protein functionalization, polyphenol coatings may be anticipated to enable potential applications ranging from biomaterials to biocatalysis, especially those that make use of materials such as cellulose, polyester, and nanostructures in general.

\section{ASSOCIATED CONTENT}

S Supporting Information

The Supporting Information is available free of charge on the ACS Publications website at DOI: 10.1021/acsami.8b13793.

Experimental protocols, example calculations of immobilized enzyme densities, and supplementary enzyme assay, XPS, NMR, HPLC, and ESI-MS data (PDF)

\section{AUTHOR INFORMATION}

\section{Corresponding Author}

*E-mail: aaron.lau@strath.ac.uk.

ORCID $\odot$

Peter J. Halling: 0000-0001-5077-4088

King Hang Aaron Lau: 0000-0003-3676-9228

\section{Author Contributions}

The manuscript was written through contributions of all authors. All authors have given approval to the final version of the manuscript.

\section{Notes}

The authors declare no competing financial interest.

\section{ACKNOWLEDGMENTS}

The authors gratefully acknowledge the financial support by, or in part by, EPSRC (EP/P511420/1 and EP/P026265/1), the Leverhulme Trust (RPG-2013-361), and the Strathclyde Academic Investment Scheme. T.-D.L. was supported by the CBET funded by the National Science Foundation under 
Grant No 1604504. They also acknowledge Dr Monica Oliveira and Dr Andreia Silva at Strathclyde Mechanical and Aerospace Engineering for contact angle measurements, Ailsa Wright and Holly McGregor for MS and HPLC measurements, and the Stewart fund at Strathclyde Chemistry for equipment funding. The research data associated with this article are available at the following link: http://dx.doi.org/10. 15129/dd9a0723-686f-4212-8255-e5745f10a88e.

\section{REFERENCES}

(1) Magner, E. Immobilisation of Enzymes on Mesoporous Silicate Materials. Chem. Soc. Rev. 2013, 42, 6213-6222.

(2) Rahim, M. A.; Ejima, H.; Cho, K. L.; Kempe, K.; Müllner, M.; Best, J. P.; Caruso, F. Coordination-Driven Multistep Assembly of Metal-Polyphenol Films and Capsules. Chem. Mater. 2014, 26, 16451653.

(3) Gray, C. J.; Weissenborn, M. J.; Eyers, C. E.; Flitsch, S. L. Enzymatic Reactions on Immobilised Substrates. Chem. Soc. Rev. 2013, 42, 6378-6405.

(4) Hartmann, M.; Kostrov, X. Immobilization of enzymes on porous silicas - benefits and challenges. Chem. Soc. Rev. 2013, 42, 6277-6289.

(5) Liu, Y.; Ai, K.; Lu, L. Polydopamine and Its Derivative Materials: Synthesis and Promising Applications in Energy, Environmental, and Biomedical Fields. Chem. Rev. 2014, 114, 5057-5115.

(6) Conte, M. P.; Sahoo, J. K.; Abul-Haija, Y. M.; Lau, K. H. A.; Ulijn, R. V. Biocatalytic Self-Assembly on Magnetic Nanoparticles. ACS Appl. Mater. Interfaces 2018, 10, 3069-3075.

(7) Zelzer, M.; Todd, S. J.; Hirst, A. R.; McDonald, T. O.; Ulijn, R. V. Enzyme Responsive Materials: Design Strategies and Future Developments. Biomater. Sci. 2013, 1, 11-39.

(8) Sassolas, A.; Blum, L. J.; Leca-Bouvier, B. D. Immobilization Strategies to Develop Enzymatic Biosensors. Biotechnol. Adv. 2012, 30, 489-511.

(9) Hartmann, M. Ordered Mesoporous Materials for Bioadsorption and Biocatalysis. Chem. Mater. 2005, 17, 4577-4593.

(10) Lu, D.; Cardiel, J.; Cao, G.; Shen, A. Q. Nanoporous Scaffold with Immobilized Enzymes during Flow-Induced Gelation for Sensitive H2O2Biosensing. Adv. Mater. 2010, 22, 2809-2813.

(11) O'Connor, E. F.; Paterson, S.; de la Rica, R. Naked-Eye Detection as a Universal Approach to Lower the Limit of Detection of Enzyme-Linked Immunoassays. Anal. Bioanal. Chem. 2016, 408, 3389-3393.

(12) Zhou, Z.; Hartmann, M. Recent Progress in Biocatalysis with Enzymes Immobilized on Mesoporous Hosts. Top. Catal. 2012, 55, $1081-1100$

(13) Secundo, F. Conformational Changes of Enzymes Upon Immobilisation. Chem. Soc. Rev. 2013, 42, 6250-6261.

(14) Sheldon, R. A.; van Pelt, S. Enzyme Immobilisation in Biocatalysis: Why, What and How. Chem. Soc. Rev. 2013, 42, 62236235.

(15) Sheldon, R. A. Enzyme Immobilization: The Quest for Optimum Performance. Adv. Synth. Catal. 2007, 349, 1289-1307.

(16) Bayne, L.; Ulijn, R. V.; Halling, P. J. Effect of Pore Size on the Performance of Immobilised Enzymes. Chem. Soc. Rev. 2013, 42, 9000-9010.

(17) Brena, B.; González-Pombo, P.; Batista-Viera, F. Immobilization of Enzymes: A Literature Survey. In Immobilization of Enzymes and Cells, 3rd ed.; Guisan, J. M., Ed.; Humana Press: Totowa, NJ, 2013; pp 15-31.

(18) Hanefeld, U.; Gardossi, L.; Magner, E. Understanding Enzyme Immobilisation. Chem. Soc. Rev. 2009, 38, 453-468.

(19) Xu, Z.; Wan, L.; Huang, X. Surface Engineering of Polymer Membranes; Springer, 2009.

(20) Liston, E. M.; Martinu, L.; Wertheimer, M. R. Plasma Surface Modification of Polymers for Improved Adhesion: A Critical Review. J. Adhes. Sci. Technol. 1993, 7, 1091-1127.
(21) Sperling, R. A.; Parak, W. J. Surface Modification, Functionalization and Bioconjugation of Colloidal Inorganic Nanoparticles. Philos. Trans. R. Soc., A 2010, 368, 1333-1383.

(22) Barbosa, O.; Torres, R.; Ortiz, C.; Berenguer-Murcia, Á.; Rodrigues, R. C.; Fernandez-Lafuente, R. Heterofunctional Supports in Enzyme Immobilization: From Traditional Immobilization Protocols to Opportunities in Tuning Enzyme Properties. Biomacromolecules 2013, 14, 2433-2462.

(23) Hong, S.; Yeom, J.; Song, I. T.; Kang, S. M.; Lee, H.; Lee, H. Pyrogallol 2-Aminoethane: A Plant Flavonoid-Inspired Molecule for Material-Independent Surface Chemistry. Adv. Mater. Interfaces 2014, 1,1400113 .

(24) Datta, S.; Christena, L. R.; Rajaram, Y. R. S. Enzyme Immobilization: An Overview on Techniques and Support Materials. 3 Biotech 2013, 3, 1-9.

(25) Sileika, T. S.; Barrett, D. G.; Zhang, R.; Lau, K. H. A.; Messersmith, P. B. Colorless Multifunctional Coatings Inspired by Polyphenols Found in Tea, Chocolate, and Wine. Angew. Chem., Int. Ed. 2013, 52, 10766-10770.

(26) Lee, H.; Dellatore, S. M.; Miller, W. M.; Messersmith, P. B. Mussel-Inspired Surface Chemistry for Multifunctional Coatings. Science 2007, 318, 426-430.

(27) Dreyer, D. R.; Miller, D. J.; Freeman, B. D.; Paul, D. R.; Bielawski, C. W. Perspectives on Poly(Dopamine). Chem. Sci. 2013, 4, 3796-3802.

(28) Dreyer, D. R.; Miller, D. J.; Freeman, B. D.; Paul, D. R.; Bielawski, C. W. Elucidating the Structure of Poly(Dopamine). Langmuir 2012, 28, 6428-6435.

(29) Barrett, D. G.; Sileika, T. S.; Messersmith, P. B. Molecular Diversity in Phenolic and Polyphenolic Precursors of Tannin-Inspired Nanocoatings. Chem. Commun. 2014, 50, 7265-7268.

(30) Ejima, H.; Richardson, J. J.; Liang, K.; Best, J. P.; van Koeverden, M. P.; Such, G. K.; Cui, J.; Caruso, F. One-Step Assembly of Coordination Complexes for Versatile Film and Particle Engineering. Science 2013, 341, 154-157.

(31) Kim, S.; Kwak, S.; Lee, S.; Cho, W. K.; Lee, J. K.; Kang, S. M. One-step functionalization of zwitterionic poly[(3(methacryloylamino)propyl)dimethyl(3-sulfopropyl)ammonium hydroxide] surfaces by metal-polyphenol coating. Chem. Commun. 2015, 51, 5340-5342.

(32) Boath, A. S.; Stewart, D.; McDougall, G. J. Berry components inhibit $\alpha$-glucosidase in vitro: Synergies between acarbose and polyphenols from black currant and rowanberry. Food Chem. 2012, 135, 929-936.

(33) Yang, H.; Landis-Piwowar, K.; Chan, T. H.; Dou, Q. P. Green Tea Polyphenols as Proteasome Inhibitors: Implication in Chemoprevention. Curr. Cancer Drug Targets 2011, 11, 296-306.

(34) Roseiro, L. B.; Rauter, A. P.; Serralheiro, M. L. M. Polyphenols as Acetylcholinesterase Inhibitors: Structural Specificity and Impact on Human Disease. Nutr. Aging 2012, 1, 99-111.

(35) Conte, M. P.; Lau, K. H. A.; Ulijn, R. V. Biocatalytic SelfAssembly Using Reversible and Irreversible Enzyme Immobilization. ACS Appl. Mater. Interfaces 2017, 9, 3266-3271.

(36) Lee, J. S.; Lee, J. S.; Lee, M. S.; An, S.; Yang, K.; Lee, K.; Yang, H. S.; Lee, H.; Cho, S.-W. Plant Flavonoid-Mediated Multifunctional Surface Modification Chemistry: Catechin Coating for Enhanced Osteogenesis of Human Stem Cells. Chem. Mater. 2017, 29, 43754384.

(37) Córdoba, A.; Monjo, M.; Hierro-Oliva, M.; González-Martín, M. L.; Ramis, J. M. Bioinspired Quercitrin Nanocoatings: A Fluorescence-Based Method for Their Surface Quantification, and Their Effect on Stem Cell Adhesion and Differentiation to the Osteoblastic Lineage. ACS Appl. Mater. Interfaces 2015, 7, 1685716864.

(38) Abouelmagd, S. A.; Meng, F.; Kim, B.-K.; Hyun, H.; Yeo, Y. Tannic Acid-Mediated Surface Functionalization of Polymeric Nanoparticles. ACS Biomater. Sci. Eng. 2016, 2, 2294-2303.

(39) Li, J.; Wu, S.; Wu, C.; Qiu, L.; Zhu, G.; Cui, C.; Liu, Y.; Hou, W.; Wang, Y.; Zhang, L.; Teng, I.-t.; Yang, H.-H.; Tan, W. Versatile 
Surface Engineering of Porous Nanomaterials with Bioinspired Polyphenol Coatings for Targeted and Controlled Drug Delivery. Nanoscale 2016, 8, 8600-8606.

(40) Allais, M.; Meyer, F.; Ball, V. Multilayered films made from tannic acid and alkaline phosphatase with enzymatic activity and electrochemical behavior. J. Colloid Interface Sci. 2018, 512, 722-729.

(41) Xu, G.; Pranantyo, D.; Zhang, B.; Xu, L.; Neoh, K.-G.; Kang, E.-T. Tannic Acid Anchored Layer-by-Layer Covalent Deposition of Parasin I Peptide for Antifouling and Antimicrobial Coatings. RSC Adv. 2016, 6, 14809-14818.

(42) Cazzola, M.; Vernè, E.; Cochis, A.; Sorrentino, R.; Azzimonti, B.; Prenesti, E.; Rimondini, L.; Ferraris, S. Bioactive Glasses Functionalized with Polyphenols: In Vitro Interactions with Healthy and Cancerous Osteoblast Cells. J. Mater. Sci. 2017, 52, 9211-9223.

(43) Fang, Y.; Tan, J.; Lan, T.; Foo, S. G. F.; Pyun, D. G.; Lim, S.; Kim, D.-H. Universal one-pot, one-step synthesis of core-shell nanocomposites with self-assembled tannic acid shell and their antibacterial and catalytic activities. J. Appl. Polym. Sci. 2018, 135, 45829.

(44) Shin, M.; Lee, H. Gallol-Rich Hyaluronic Acid Hydrogels: Shear-Thinning, Protein Accumulation against Concentration Gradients, and Degradation-Resistant Properties. Chem. Mater. 2017, 29, $8211-8220$

(45) Lilly, M. D.; Dunnill, P. Immobilized-Enzyme Reactors. Methods in Enzymology; Academic Press, 1976; pp 717-738.

(46) Kang, C.-K.; Lee, Y.-S. The Surface Modification of Stainless Steel and the Correlation between the Surface Properties and Protein Adsorption. J. Mater. Sci.: Mater. Med. 2007, 18, 1389-1398.

(47) Zhang, L.; Cao, X.; Wang, L.; Zhao, X.; Zhang, S.; Wang, P. Printed Microwells with Highly Stable Thin-Film Enzyme Coatings for Point-of-Care Multiplex Bioassay of Blood Samples. Analyst 2015, 140, 4105-4113.

(48) Cao, R.; Tian, W.; Shen, W. Polysaccharides as Protectants for Paper-Based Analytical Devices with Antibody. Talanta 2017, 165, 357-363.

(49) Araujo, C. L.; Vihko, P. T. Structure of Acid Phosphatases. Methods Mol. Biol. 2013, 1053, 155-166.

(50) Lewis, G. P. The Importance of Ionization in the Activity of Sympathomimetic Amines. Br. J. Pharmacol. Chemother. 1954, 9, 488-493.

(51) Kang, S. M.; Hwang, N. S.; Yeom, J.; Park, S. Y.; Messersmith, P. B.; Choi, I. S.; Langer, R.; Anderson, D. G.; Lee, H. One-Step Multipurpose Surface Functionalization by Adhesive Catecholamine. Adv. Funct. Mater. 2012, 22, 2949-2955.

(52) Sugiura, Y.; Kawabe, H.; Tanaka, H.; Fujimoto, S.; Ohara, A. Purification, Enzymatic Properties, and Active Site Environment of a Novel Manganese(III)-Containing Acid Phosphatase. J. Biol. Chem. 1981, 256, 10664-10670.

(53) Dai, J.; Mumper, R. J. Plant Phenolics: Extraction, Analysis and Their Antioxidant and Anticancer Properties. Molecules 2010, 15, 7313-7352.

(54) Haslam, E. Plant polyphenols (syn. vegetable tannins) and chemical defense?A reappraisal. J. Chem. Ecol. 1988, 14, 1789-1805.

(55) Adányi, N.; Barna, T.; Emri, T.; Miskei, M.; Pócsi, I. Hydrogen Peroxide Producing and Decomposing Enzymes: Their Use in Biosensors and Other Applications. In Industrial Enzymes: Structure, Function and Applications; Polaina, J., MacCabe, A. P., Eds.; Springer Netherlands: Dordrecht, 2007; pp 441-459.

(56) Spulber, M.; Baumann, P.; Saxer, S. S.; Pieles, U.; Meier, W.; Bruns, N. Poly(N-Vinylpyrrolidone)-Poly(Dimethylsiloxane)-Based Polymersome Nanoreactors for Laccase-Catalyzed Biotransformations. Biomacromolecules 2014, 15, 1469-1475.

(57) Call, H. P.; Mücke, I. History, overview and applications of mediated lignolytic systems, especially laccase-mediator-systems (Lignozym-process). J. Biotechnol. 1997, 53, 163-202. 